\title{
ESTIMATING GREENHOUSE GAS EMISSIONS LEVEL OF A NATURAL GAS PIPELINE - CASE STUDY FROM A TO B POINT IN WEST JAVA-INDONESIA
}

\author{
Cindy Dianita, Asep Handaya Saputra \\ Department of Chemical Engineering, Faculty of Engineering, University of Indonesia \\ E-mail : cindydianita@yahoo.com
}

\begin{abstract}
Indonesia is one of the highest greenhouse emitters in the world. As a response of this problem, Indonesia declared the national action plan to focus on national greenhouse gas (GHG) reduction by $26 \%$ by 2020 . To achieve this target, Government puts energy sector as one of the top priorities since it is the second strongest contributor to national GHG emissions. The main purpose of this paper is to apply the method of fugitive emissions calculation to the existing natural gas pipeline in Indonesia. Fugitive emissions are the major component of GHG emissions from natural gas systems and methane $\left(\mathrm{CH}_{4}\right)$, the primary component of natural gas pipeline, is a potent GHG. Tiered approaches from Interstate Natural Gas Association of America (INGAA) are implemented in this paper as the estimation guidelines. A case study of a natural gas pipeline system in Indonesia is analyzed to compare the GHG emissions level resulted from Tier 1 and Tier 2 methods. In these methods, the input data are pipeline length, the number of compressor stations, and the number of meter and pressure regulation stations. In this case, the GHG emissions level of Tier 2 is significantly different from Tier 1. The variation of pipeline length shows that for the length under 479.2 miles, Tier 1 gives lower amount of $\mathrm{CO}_{2}$ equivalent than Tier 2 . The differences of these estimation methods and results can be furtherly developed to provide relevant information and recommendation for the Companies and Government to record the emissions level from natural gas transmission pipeline according to their needs and purposes.
\end{abstract}

Keywords: emissions, GHG, pipeline, Indonesia

\section{INTRODUCTION}

The demand for energy in Indonesia will continue to grow in the coming years and the domestic consumption for natural gas is increasing fast. The government of Indonesia through The Ministry of Energy and Mineral Resources launched the National Gas Policy Roadmap 2014-2030. This book records the strong demand for gas is expected to be significantly high in 2015- 2025 because the government sets the target to optimize the consumption of natural gas in domestic market as it is environmentally friendly fuel and cheaper than other fossil fuels. This target also in line with the national target of a $26 \%$ reduction in Greenhouse Gas (GHG) emissions by 2020 .

Currently, the transportation of natural gas in Indonesia is dominated by pipeline and the government of Indonesia plans to build transmission and distribution pipelines of natural gas to supply a range of customers across the country. Compared with other forms of transport, pipelines provide more continuous, stable, and high-capacity [1].

Although natural gas is considered as clean fuel, the issue of indirect GHG emissions from gas production and transport has come up in the discussions about the energy supply [2]. It is a potent GHG when it is released into the atmosphere as uncombusted methane. The U.S. Environmental Protection Agency (EPA) reported the fugitive emissions of methane from oil and gas extraction and pipeline transmission are the main anthropogenic source of methane in the United States and the second largest source globally [3]. Interstate Natural Gas Association of America (INGAA) stated that fugitive emissions are the biggest methane emission source account for transmission sector [4]. Methane is a far more potent greenhouse gas $\mathrm{GHG}$ than $\mathrm{CO}_{2}$ with an estimated global warming potential 86 times greater than $\mathrm{CO} 2$ on a 20 year basis and 34 times greater on a 100 year basis $[5,6,7,8,9]$. GHG emissions from natural gas delivery must be quantified to evaluate the environmental impacts of natural gas transportation and to develop the emission reduction strategies.

The main purpose of this paper is to apply the emission estimation methodologies INGAA to calculate the fugitive emissions of the existing natural gas pipeline in Indonesia using Tier 1 and Tier 2 methods.

INGAA is a trade organization that advocates regulatory and legislative positions of importance to the natural gas pipeline industry in North America. The guidelines published by INGAA are not only implemented in the US but also have become the references for natural gas industry in other countries.

In Indonesia, the guidelines for GHG emissions refers to the Intergovernmental Panel on Climate Change (IPCC) guidelines for national GHG inventories. Thus, most of GHG emissions of gas pipeline in Indonesia is reported on the basis of IPCC. This paper is intended to characterize the GHG emissions of a natural gas pipeline system in West Java, Indonesia by referring to INGAA methodologies and procedures. Moreover, the differences of these estimation methods and results from Tier 1 and Tier 2 methods can be furtherly developed to provide relevant information and recommendation for the Companies and Government to record the emissions level 
from natural gas transmission pipeline according to their needs and purposes.

\section{METHODOLOGY}

Indonesia Ministry of Environment defines fugitive emissions as unintentional leaks from any activities of energy production and distribution such as flaring, venting, leaks from pipe connection and valves and methane release from coal mining activities [10]. In general, fugitive emissions from oil and gas activities may be attributed to the several sources: fugitive equipment leaks, process venting, evaporation losses, disposal of waste gas streams by venting or flaring, accidents and equipment failures [11].

There are 3 tiers in estimating the emission of gas pipeline system by referring to INGAA guidelines. Due to the availability of the data, GHG emissions are calculated on the basis of Tier 1 and Tier 2.Tier 1 method only requires pipeline length while Tier 2 calculates the fugitive emission of transmission pipeline based on pipeline length as well as the quantity of compressor stations and meter/regulator stations. Table 1 and Table 2 summarize the emission factors for fugitive emissions based on Tier 1 and Tier 2 methods. GHG emissions are calculated by multiplying the activity data by the emission factor. The methane fugitive emissions is then converted using Global Warming Potential (GWP) of gas to get the number of $\mathrm{CO}_{2}$ equivalent.

Table-1. Emission Factors for Fugitive Emissions of Tier 1

\begin{tabular}{|l|c|c|l|}
\hline Activity Data & $\mathrm{GHG}$ & $\begin{array}{c}\text { Emission } \\
\text { Factor }\end{array}$ & $\begin{array}{l}\text { Emission } \\
\text { Factor Units }\end{array}$ \\
\hline \multirow{2}{*}{$\begin{array}{l}\text { Pipeline } \\
\text { length }\end{array}$} & $\mathrm{CH}_{4}$ & 7923 & $\begin{array}{l}\text { lb } \mathrm{CH}_{4} / \mathrm{mile}- \\
\text { year }\end{array}$ \\
\cline { 2 - 4 } & $\mathrm{CO}_{2}{ }^{1}$ & 7.59 & $\begin{array}{l}\text { lb } \mathrm{CO}_{2} / \text { mile- } \\
\text { year }\end{array}$ \\
\cline { 2 - 4 } & $\mathrm{CO}_{2}{ }^{2}$ & 466.7 & $\begin{array}{l}\text { lb } \mathrm{CO}_{2} / \mathrm{mile}- \\
\text { year }\end{array}$ \\
\hline
\end{tabular}

${ }^{*} \mathrm{CO}_{2}$ from $\mathrm{CH}_{4}$ oxidation

${ }^{2} \mathrm{CO}_{2}$ from pipeline leaks

The calculations of GHG emissions for a natural gas pipeline system from A to B Point in West Java (Indonesia) have been performed. The total length of this gas transmission pipeline system counts $220 \mathrm{~km}$ and contains 3 compressor stations and 3 meter/regulator stations. The fractions of $\mathrm{CH}_{4}$ and $\mathrm{CO}_{2}$ in the natural gas are assumed as $93.4 \%$ and $2 \%$ respectively.
Table-2. Emission Factors for Fugitive Emissions of Tier 2

\begin{tabular}{|c|c|c|c|}
\hline Activity Data & GHG & $\begin{array}{l}\text { Emission } \\
\text { Factor }\end{array}$ & $\begin{array}{c}\text { Emission } \\
\text { Factor Units }\end{array}$ \\
\hline \multirow{3}{*}{ Pipeline length } & $\mathrm{CH}_{4}$ & 23.08 & $\begin{array}{l}\mathrm{lb} \mathrm{CH}_{4} / \text { mile- } \\
\text { year }\end{array}$ \\
\hline & $\mathrm{CO}_{2}{ }^{1}$ & 7.59 & $\begin{array}{l}\mathrm{lb} \mathrm{CO}_{2} / \mathrm{mile}- \\
\text { year }\end{array}$ \\
\hline & $\mathrm{CO}_{2}^{2}$ & 1.52 & $\begin{array}{l}\mathrm{lb} \quad \mathrm{CO}_{2} / \text { mile- } \\
\text { year }\end{array}$ \\
\hline \multirow{2}{*}{$\begin{array}{l}\text { Number of } \\
\text { compressor } \\
\text { station }\end{array}$} & $\mathrm{CH}_{4}$ & 1259400 & $\begin{array}{l}\mathrm{lb} \\
\mathrm{CH}_{4} / \text { station- } \\
\text { year }\end{array}$ \\
\hline & $\mathrm{CO}_{2}$ & 72747 & $\begin{array}{l}\mathrm{lb} \\
\mathrm{CO}_{2} / \text { station- } \\
\text { year }\end{array}$ \\
\hline \multirow{2}{*}{$\begin{array}{l}\text { Number of } \\
\text { meter/regulator } \\
\text { station }\end{array}$} & $\mathrm{CH}_{4}$ & 2533 & $\begin{array}{l}\mathrm{lb} \\
\mathrm{CH}_{4} / \text { station- } \\
\text { year }\end{array}$ \\
\hline & $\mathrm{CO}_{2}$ & 146.34 & $\begin{array}{l}\mathrm{lb} \\
\mathrm{CO}_{2} / \text { station- } \\
\text { year }\end{array}$ \\
\hline
\end{tabular}

${ }^{*} \mathrm{CO}_{2}$ from $\mathrm{CH}_{4}$ oxidation

${ }^{2} \mathrm{CO}_{2}$ from pipeline leaks

\section{RESULTS AND DISCUSSIONS}

The calculation results of fugitive emissions by referring to Tier 1 and Tier 2 methods of INGAA are presented by Table 3 and Table 4 . From the two tables, it is obvious that the Tier 2 result is 3.5 times higher than Tier 1. For this case, as the Tier 2 parameter of GHG consists of 3 factors, the highest emissions comes from compressor stations (more than 99\%).A simulation is also performed to find the condition that gives the similar number of fugitive emission for both Tier 1 and Tier 2. A similar result is shown when the pipeline length is 771.2 $\mathrm{km}$. A change in number of compressor stations or meter/regulator stations cannot give the same result for the two Tiers with the same length of pipeline $(220 \mathrm{~km})$.

Table-3. Result of Tier 1 Fugitive Emissions

\begin{tabular}{|c|l|c|c|}
\hline Activity Data & \multicolumn{1}{|c|}{$\mathrm{GHG}$} & $\begin{array}{c}\text { Tonnes } \\
\mathrm{GHG} / \mathrm{mile}- \\
\text { year }\end{array}$ & $\begin{array}{c}\text { Tonnes } \\
\mathrm{CO}_{2} \\
\text { equivalent }\end{array}$ \\
\hline \multirow{2}{*}{ Pipeline length } & $\begin{array}{l}\mathrm{CH}_{4} \\
\mathrm{CO}_{2} \text { from } \\
\text { oxidation }\end{array}$ & 0.47 & 0.47 \\
\cline { 2 - 4 } & $\begin{array}{l}\mathrm{CO}_{2} \\
\text { fugitive } \\
\text { leaks }\end{array}$ & 28.94 & 28.94 \\
\hline $\begin{array}{l}\text { Tonnes CO2 } \\
\text { length }\end{array}$ & equivalent from pipeline & 10346.35 \\
\hline
\end{tabular}


Table-4. Result of Tier 2 Fugitive Emissions

\begin{tabular}{|c|c|c|c|}
\hline Activity Data & GHG & $\begin{array}{c}\text { Tonnes } \\
\text { GHG/mile- } \\
\text { year }\end{array}$ & $\begin{array}{c}\text { Tonnes } \\
\mathrm{CO}_{2} \\
\text { equivalent }\end{array}$ \\
\hline \multirow{3}{*}{ Pipeline length } & $\mathrm{CH}_{4}$ & 1.43 & 30.05 \\
\hline & $\begin{array}{l}\mathrm{CO}_{2} \text { from } \\
\text { oxidation }\end{array}$ & 0.47 & 0.47 \\
\hline & $\begin{array}{l}\mathrm{CO}_{2} \\
\text { fugitive } \\
\text { leaks }\end{array}$ & 0.09 & 0.09 \\
\hline \multicolumn{3}{|c|}{$\begin{array}{l}\text { Tonnes } \mathrm{CO} 2 \text { equivalent from pipeline } \\
\text { length }\end{array}$} & 30.62 \\
\hline \multirow{2}{*}{$\begin{array}{l}\text { Number of } \\
\text { compressor } \\
\text { stations }\end{array}$} & $\mathrm{CH}_{4}$ & 1713.78 & 35989.39 \\
\hline & $\mathrm{CO}_{2}$ & 98.99 & 98.99 \\
\hline \multicolumn{3}{|c|}{$\begin{array}{l}\text { Tonnes CO2 equivalent from compressor } \\
\text { stations }\end{array}$} & 36088.38 \\
\hline \multirow{2}{*}{$\begin{array}{l}\text { Number of } \\
\text { meter/regulator } \\
\text { station }\end{array}$} & $\mathrm{CH}_{4}$ & 3.45 & 72.38 \\
\hline & $\mathrm{CO}_{2}$ & 0.20 & 0.20 \\
\hline \multicolumn{3}{|c|}{$\begin{array}{lcc}\begin{array}{l}\text { Tonnes } \\
\text { meter/regulator stations }\end{array} & \text { equivalent } & \text { from } \\
\end{array}$} & 72.58 \\
\hline \multicolumn{3}{|c|}{$\begin{array}{l}\text { Tonnes } \mathrm{CO} 2 \text { equivalent from transmission } \\
\text { line }\end{array}$} & 36191.58 \\
\hline
\end{tabular}

From Tier 1 and Tier 2 methods, the pipeline length is considered as the parameter of fugitive emissions calculation. Referring to the definition of fugitive emission in the Guidelines of National Greenhouse Gas Inventory of Indonesia, fugitive emission is unintentional leaks from any objects in energy production and distribution. For pipeline, the connectors beteween two pipeline segments as well as valves and components attached to the pipelines are source for leaks. For this reason, the pipeline length data can be considered as the information to develop the fugitive emissions estimation.

In this work, the effects of operating pressure and diameter of gas pipeline are not calculated although they are considered as the main operating parameters for gas pipeline system. These two parameters may contribute to the pipeline leaks and identify as activity factor of emission source. However, the leaked volumes do not significantly affect the total volume of pipeline leaks [12].

The overall fugitive emissions calculation result of Tier 1 is lower than Tier 2. However, it is much higher compared to Tier 2 for pipeline length variable. It is due to the difference in emission factor. Tier 1 has higher emission factor for $\mathrm{CH}_{4}$ and $\mathrm{CO}_{2}$ from pipeline leaks to cover other variables that are not included in the calculation but considered as potential leak sources. On the other hand, Tier 2 puts smaller emission factor for pipeline length variable but complete the calculation with two other parameters i.e number of compressor stations and meter/regulator stations. From the calculation, the emissions calculation result from compressor station is the highest than pipeline length and meter/ regulator stations.

Principally, compressor is one of the main equipment in transporting natural gas through pipeline to provide adequate pressure of the gas to reach the end users. As the distance between the source and end users is far, it needs some compressor stations at certain points to maintain the operating pressure. Even in a compressor station consists of more than one compressor to gradually increase the operating pressure as a compressor has technical limitation to increase the pressure to a certain value. The compressor is worked as the result of the driver, typically a gas or diesel engine or gas turbine. The driver of compressor is a potential leak source that release GHG emissions, primarily $\mathrm{CH}_{4}$ and $\mathrm{CO}_{2}$. The higher the length of pipeline, the higher possibility of natural gas pressure drop. Consequently, it needs more compressor stations and resulting more GHG emissions. The high methane emissions as the result of compressor activity was also recorded in Russian long distance gas transport system [13]. There are some recommended options to improve the level emissions from compressor activity such as the replacement of centrifugal compressor seal oil systems and the installation of low bleed pneumatic devices [13].

Another variable of Tier 2 calculation is the number of meter/regulator stations. Meter/regulator stations are installed to measure the flow of gas along the pipeline. These stations are important to monitor, control, and account for the natural gas flow in the pipeline. The regulating equipment has vital roles as the regulator that reduce the delivery pressure to customer as well as to protect a section of a pipeline with a lower maximum operating pressure. These meter/regulator stations basically consist of meters, valves, fittings, instrumentation, and controls which contribute to the release of GHG to atmosphere. To position the pressure regulators, it is common to use gas operated pneumatic devices. These type of penumatic devices can release the gas to atmosphere when the regulator is activated. However, as the effect of leaks from meter/regulator stations is not as high as compressor stations, Tier 2 method applies lower emission factors for this activity factor.

The results of Tier 1 and Tier 2 is totally different. Principally, Tier 2 is an improvement method of Tier 1. This approach has additional activity factors but the errors from this method may be higher than Tier 1 if the facililty of the gas transmission pipeline system is different from typical industry averages. Although the accuracy of Tier 1 is less than Tier 2, but it can be used as a estimation tool to calculate emissions when the availability of the data is limited such as when the prelimanary design phase or when the facility has not been constructed yet. The quality of the data, the purpose of the estimation activity, as well as cost factor should be noticed in selecting the proper approach information. The initial estimation can be used as reference and recommendation for environmental assessment as well as preparing the GHG inventories in order to obtain government permission.

In certain conditions, the result of Tier 1 can be similar as Tier 2. For the case in this work, a similar result is obtained when the pipeline length is $771.2 \mathrm{~km}$ while the number of compressor stations and meter/regulator stations are maintained. A change in number of the stations (compressor stations or meter/regulator stations) will not give the same emission result for the length of 220 
$\mathrm{km}$. The result of Tier 2 can be lower than Tier 1 when the pipeline length is more than $771.2 \mathrm{~km}$ with the same number of compressor stations and meter/regulator stations. However, to maintain the same number of these stations is technically not possible, as the increase of the distance (pipeline length) will need more compressor stations and meter/regulator stations to control the pressure and flow rate of the natural gas along the pipeline.

\section{CONCLUSIONS}

The Tier 1 and Tier 2 methods from INGAA provide different required input data and result of gas pipeline fugitive emissions. In this work, Tier 2 shows a 3.5 times higher emission level than Tier 1 for a pipeline system in West Java, Indonesia. Although Tier 2 is developed with more detail factors of emission sources, but it does not mean that the lower accuracy method (Tier 1) can not be applied to estimate the emission level in natural gas industry. The cost for developing and documenting average facility level component counts for the estimation also need to be considered whether it is appropriate with the purpose of inventory.

\section{REFERENCES}

[1] Mohitpour, M., Botros, K, and Van Hardeveld, T. 2008. Pipeline Pumping and Compression Systems: A Practical Approach. New York: ASME, p.1.

[2] Lechtenboehmer, S., Fischedick, M., Dienst, C. and Hanke, T. 2003. GHG emissions of the natural gas life cycle compared to other fossil fuels (in Europe). Beijing: 3 rd International Methane and Nitrous Oxide Mitigation Conference, pp.790-798.

[3] U. S. Environmental Protection Agency, 2012. Methane Emissions. [online] Washington DC. Available at: http://epa.gov/climatechange [Accessed 5 Sep. 2015].

[4] Interstate Natural Gas Association of America, 2005. Greenhouse gas emission estimation guidelines for natural gas transmission and storage. Washington DC: INGAA.

[5] Shindell, D, Kuylenstierna, JCI, Faluvegi, G, Milly, G, Emberson, L, Hicks, K, Vignati, E, Van Dingenen, R, Janssens-Maenhout, G, Raes, F, Pozzoli, L, Amann, M, Klimont, Z, Kupiainen, K, Höglund-Isaksson, L, Anenberg, SC, Muller, N, Schwartz, J, Streets, D, Ramanathan, V, Oanh, NTK, Williams, M, Demkine, V, Fowler, D. 2012. Simultaneously Mitigating Near-Term Climate Change and Improving Human Health and Food Security. Science, 335(6065), pp.183-189.

[6] Howarth, R., Shindell, D., Santoro, R., Ingraffea, A., Phillips, N. and Townsend-Small, A. 2012. Methane Emissions from Natural Gas Systems. National Climate Assessment, (Ref. no. 2011-0003).

[7] Alvarez, R.A, Pacala, S., Winebrake, J., Chameides, W. and Hamburg, S. 2012. Greater focus needed on methane leakage from natural gas infrastructure.
Proceedings of The National Academy of Sciences of The United States of America, p.Vol 109, no.17.

[8] Townsend-Small, A., Tyler, S., Pataki, D., Xu, X. and Christensen, L. 2012. Isotopic measurements of atmospheric methane in Los Angeles, California, USA: Influence of fugitive fossil fuel emissions. Journal of Geophysical Research, 117(D7).

[9] Schlesinger, W. and Bernhardt, E. 2013. Biogeochemistry: An Analysis of Global Change. 3rd ed. San Diego CA: Academic Press.

[10] Indonesia Ministry of Environment, 2012. Pedoman penyelenggaraan inventarisasi gas rumah kaca nasional. Jakarta: Indonesia Ministry of Environment.

[11] Picard, D. 2006. Fugitive Emissions from Oil and Natural Gas Activities, Good Practice Guidance and Uncertainty Management in National Greenhouse Gas. [online] IPCC. Available at: http://www.ipccnggip.iges.or.jp/public/gp/bgp/2_6_Fugitive_Emissions_fr om_Oil_and_Natural_Gas.pdf [Āccessed 22 Aug. 2015].

[12] Campbell, L. and Stapper, B. 1996. Methane Emissions From The Natural Gas Industry. U.S. Environmental Protection Agency.

[13] Lechtenböhmer, S., Dienst, C., Fischedick, M., Hanke, T., Fernandez, R., Robinson, D., Kantamaneni, R. and Gillis, B. 2007. Tapping the leakages: Methane losses, mitigation options and policy issues for Russian long distance gas transmission pipelines. International Journal of Greenhouse Gas Control, 1(4), pp.387-395. 